\title{
Effect of Sodium Hypochlorite and EDTA Irrigation, Individually and in Alternation, on Dentin Microhardness at the Furcation Area of Mandibular Molars
}

\author{
Danilo ZAPAROLLI \\ Paulo César SAQUY \\ Antonio Miranda CRUZ-FILHO \\ Department of Restorative Dentistry, Ribeirão Preto Dental School, \\ USP - University of São Paulo, Ribeirão Preto, SP, Brazil
}

\begin{abstract}
The aim of this study was to evaluate the effect of irrigation regimens on dentin microhardness at the furcation area of mandibular molars, using sodium hypochlorite and ethylenediaminetetraacetic acid (EDTA), individually and in alternation. The occlusal surface and the roots of 20 non-carious extracted human permanent mandibular molars were cut transversally and discarded. The tooth blocks were embedded in acrylic resin and randomly assigned to 4 groups $(n=5)$ according to the irrigating regimens: $1 \% \mathrm{NaOCl}$ solution, $17 \%$ EDTA solution, $1 \% \mathrm{NaOCl}$ and $17 \%$ EDTA and distilled water (control). Knoop microhardness of dentin at the furcation area was evaluated. Data were analyzed using one-way ANOVA and Tukey's multiple comparison tests $(\alpha=0.05)$. The results of this study indicated that all irrigation solutions, except for distilled water (control), decreased dentin microhardness. EDTA did not show a significant difference with $\mathrm{NaOCl} / \mathrm{EDTA}(\mathrm{p}>0.05)$, but showed a significant difference with $\mathrm{NaOCl}(\mathrm{p}<0.01)$. EDTA and NaOCl/EDTA showed a maximum decrease in microhardness. The $17 \%$ EDTA solution, either alone or in combination with $1 \% \mathrm{NaOCl}$ reduced significantly dentin microhardness at the furcation area of mandibular molars.
\end{abstract}

Key Words: irrigating solutions, microhardness, ethylenediamine tetraacetic acid, sodium hypochlorite.

\section{INTRODUCTION}

The smear layer produced by files and drills during root canal instrumentation is a film of debris attached to dentin surface, composed by excised dentin particles, remnants of vital or necrotic pulp tissue, microorganisms and their byproducts, and retained chemical irrigants (1). If not removed, the smear layer has a negative impact on root canal adhesion because it will act as a physical barrier between the filling material and canal walls, undermining sealer penetration and formation of intratubular tags (2). It is also believed that removing this layer could dissolve the attached microbiota and their toxins from root canal walls and reduce the potential of bacterial survival and reproduction (3).

Although several chemical agents are available with different properties, as far as cleaning of root canals is concerned, no currently available endodontic irrigant fulfills all ideal physicochemical properties to act simultaneously on the organic and inorganic components of smear layer (4). So, the combination of auxiliary solutions is necessary to achieve the desired outcomes. A recognizably efficient protocol for removal of smear layer is the use of sodium hypochlorite $(\mathrm{NaOCl})$ in concentrations ranging from $0.5 \%$ to $6.15 \%$ and $17 \%$ ethylenediaminetetraacetic acid (EDTA) as initial and final irrigating solutions, respectively (5).

Human dentin is composed by approximately $70 \%$ of inorganic material, $20 \%$ of organic material and $10 \%$ of water. Ninety percent of the organic matter is collagen, which plays a major mechanical role in dentin (6). Depletion of the organic phase after root canal irrigation with $\mathrm{NaOCl}$ may cause changes in the mechanical properties, including microhardness $(7,8)$.

Correspondence: Prof. Dr. Antonio M. Cruz-Filho, Departamento de Odontologia Restauradora, Faculdade de Odontologia de Ribeirão Preto, USP, Avenida do Café, S/N, 14040-904 Ribeirão Preto, SP, Brasil. Tel: +55-16-3602-4792. Fax: +55-16-3633-0999. e-mail: cruz@forp.usp.br 
However, endodontic irrigants may alter the physicochemical properties of dentin $(3,9) \cdot \mathrm{NaOCl}$ causes oxidation of the organic matrix and denaturation of collagen, changing the chemical structure of dentin and affecting its mechanical properties (10). Oliveira et al. (11) reported that $1 \% \mathrm{NaOCl}$ decreased root dentin microhardness to depths up to $1,000 \mu \mathrm{m}$ from the canal lumen. EDTA demineralizes the inorganic components of dentin by chelating calcium ions, which reduces the microhardness (12). A previous study showed that $17 \%$ EDTA, either alone or in combination with a tensoactive cationic detergent (Cetavlon) caused a more significant reduction of root dentin microhardness than $10 \%$ citric acid (13). Cruz-Filho et al. (14) reported that the action of 17\% EDTA in decreasing dentin microhardness can be observed within the first minute after application of this chelator and that dentin microhardness decreases as the contact time with the solution increases.

There is extensive scientific literature on the action of different chelating and demineralizing solutions on the microhardness of root dentin thirds and canal lumen (7,8,11-15). However, little is known about the action of the chelating agents on the microhardness of the furcation area of teeth. The aim of this study was to evaluate the effect of irrigation regimens on dentin microhardness at the furcation area of mandibular molars, using $1 \% \mathrm{NaOCl}$ and $17 \%$ EDTA, individually and in alternation.

\section{MATERIAL AND METHODS}

The research protocol was approved by the institutional Ethics Committee (Process \#2010.1.1118.58.9). Twenty human mandibular molars from the institutional Human Tooth Bank were used in the study. Using a water-cooled double-faced diamond disc in a high-speed handpiece, the occlusal surface was removed to expose the pulp chamber and the mesial and distal roots were cut transversally approximately 5 $\mathrm{mm}$ below the cementoenamel junction and discarded, producing 20 tooth blocks. The pulp tissue remaining in the canal lumen was removed with a Hedströem file (Kerr UK, Peterborough, UK). The canal apical opening was sealed with light-cured composite resin and the access to the pulp chamber was left open. The tooth blocks were stored in sterile saline at $4^{\circ} \mathrm{C}$ for 24 $\mathrm{h}$ and thereafter embedded in self-curing, fast setting acrylic resin, except for the occlusal side. The tooth/ acrylic resin block sets were distributed into 4 groups of
5 specimens each, according to the irrigation regimens: $1 \% \mathrm{NaOCl}, 17 \%$ EDTA, $1 \% \mathrm{NaOCl}+17 \%$ EDTA and distilled water (control). A standardized volume of 0.5 $\mathrm{mL}$ of each irrigating solution was delivered directly to pulp chamber using an automated micropipette. After 10 min, the pulp chamber was copiously rinsed with $10 \mathrm{~mL}$ of distilled water to remove any residues of the tested solution. In the group where both chemical irrigants were used, $0.5 \mathrm{~mL}$ of $1 \% \mathrm{NaOCl}$ was delivered for $10 \mathrm{~min}$, followed by aspiration, delivery of $0.5 \mathrm{~mL}$ of $17 \%$ EDTA for $10 \mathrm{~min}$ and final flush with $10 \mathrm{~mL}$ of distilled water. After the treatments, the tooth/acrylic resin block sets were bisected longitudinally in a mesiodistal direction in a high-precision cutting machine (Struers; Minitom, Copenhagen, Denmark) and the halves considered the most representative of the furcation area were selected. The specimens were ground wet with 400-, 500- and 600 -grit silicon carbide papers and polished with felt discs (Diamond; FGM, Joinvile, SC, Brazil) embedded in aluminum oxide paste (Alpha micropolish LC; Union Carbide Corp., Houston, TX, USA) at low speed. The specimens were washed in running water for $4 \mathrm{~h}$, dried with gauze and examined at $\times 40$ magnification to confirm their smoothness. These procedures are necessary because measurement of microhardness is only possible on smooth dentin surface. The indentations are not visible on non-polished surfaces.

The furcation area to be examined (F) was delimited with a \#15 scalpel blade by tracing two orthogonal lines, which started from a point (C) located on the outer surface of the root in the most concave portion of the furcation, extending up to the pulp chamber floor, towards the entrance of mesial and distal canals (Fig. 1A). Dentin microhardness was measured in this region with a Knoop indenter (Shimadzu HMV2000; Shimadzu Corporation, Kyoto, Japan) under 10

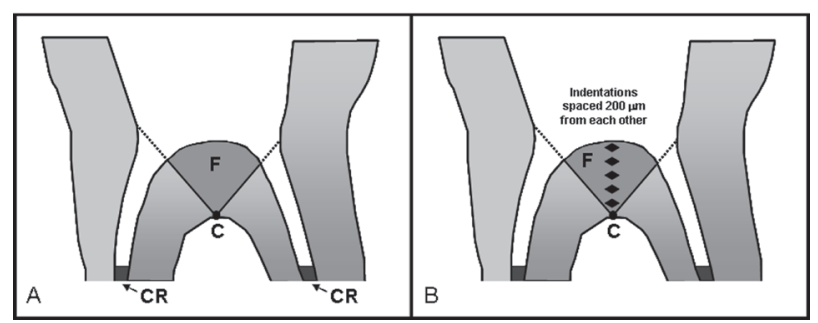

Figure 1. A: Delimited furcation area, showing the analyzed region $(\mathrm{F})$, maximum concavity point of the furcation area $(\mathrm{C})$, composite resin restoration (CR). B: Indentation scheme on the furcation area. 
$\mathrm{g}$ load and $15 \mathrm{~s}$ dwell time. Five indentations spaced $200 \mu \mathrm{m}$ from each other were made in each specimen, following a direction parallel to the bisecting line between the orthogonal lines, starting from the pulp chamber floor towards the point "C" (Fig. 1B). The representative dentin microhardness value for each specimen was obtained as the average of the results for the five indentations. Data were analyzed statistically by one-way ANOVA and Tukey's multiple-comparison test using GraphPad InStat, v.3, software (GraphPad Software Inc., San Diego, CA, USA). A significance level of $5 \%$ was set for all analyses.

\section{RESULTS}

The Knoop microhardness values (mean $\pm \mathrm{SD}$ ) for the irrigating regimens are summarized in Table 1. Statistically significant difference was detected among the irrigating solutions $(p<0.0001)$. The results showed that all irrigating solutions, except for distilled water (control), decreased dentin microhardness.

EDTA differed significantly $(\mathrm{p}<0.01)$ from $\mathrm{NaOCl}$ and distilled water, but did not show a significant difference $(\mathrm{p}>0.05)$ from $\mathrm{NaOCl} / \mathrm{EDTA}$. $\mathrm{NaOCl}$ showed a significant difference $(p<0.01)$ from distilled water. EDTA alone or in combination with $\mathrm{NaOCl}$ had the greatest overall effect on dentin microhardness, causing a sharper decrease compared with the other solutions $(p<0.01)$, but without statistically significant difference between them $(\mathrm{p}>0.05)$.

\section{DISCUSSION}

$\mathrm{NaOCl}$ has been systematically used as an endodontic irrigant for the chemomechanical preparation of root canals because of its excellent antimicrobial action, capacity of dissolving organic tissue remnants and improving the action of instruments and drills

Table 1. Knoop microhardness values (mean $\pm \mathrm{SD}$ ) of root canal dentin after the irrigating regimens.

\begin{tabular}{ll}
\hline Solution & Mean \pm SD \\
\hline EDTA & $38.5 \pm 1.4^{\mathrm{a}}$ \\
$\mathrm{NaOCl}$ & $48.3 \pm 2.4^{\mathrm{b}}$ \\
$\mathrm{NaOCl}+$ EDTA & $37.7 \pm 1.7^{\mathrm{a}}$ \\
$\mathrm{Control}$ & $67.4 \pm 3.4^{\mathrm{c}}$ \\
\hline
\end{tabular}

Different letters indicate statistically significant difference $(p<0.05)$. by lubricating the dentin canal walls. Final irrigation with 17\% EDTA for $2 \mathrm{~min}$ has been recommended for removal of smear layer from root canal walls, especially at the cervical and middle thirds (12). Therefore, in the present study, $1 \% \mathrm{NaOCl}$ and $17 \%$ EDTA were used individually and in alternation to evaluate the effect of these irrigating regimens on dentin microhardness at the furcation area. Microhardness determination can provide indirect evidence of mineral loss or gain in the dental hard tissues (16). Knoop indenter microhardness test has been used in previous studies to measure dentin microhardness and the suitability and practicality of this test for evaluating surface changes of dental hard tissues treated with chemical agents has been demonstrated $(7,12)$.

In the present study, $1 \% \mathrm{NaOCl}$ reduced significantly dentin microhardness at the furcation area when compared with distilled water (control group). Kinney et al. (6) suggested that the decrease in hardness is caused by a decrease in stiffness of intertubular dentin matrix caused by heterogeneous distribution of the mineral phase within the collagen matrix. SlutzkyGoldberg et al. (8) found that root canal irrigation with $2.5 \%$ and $6 \% \mathrm{NaOCl}$ reduced dentin microhardness at a depth of $500 \mu \mathrm{m}$ from the canal lumen. According to those authors, both the concentration and the irrigation period affect the action of $\mathrm{NaOCl}$ in reducing microhardness. Oliveira et al. (11) stated that the use of $1 \% \mathrm{NaOCl}$ for 15 min was sufficient to reduce dentin microhardness at depths up to $1,000 \mu \mathrm{m}$ from the canal lumen.

Irrigation with $1 \% \mathrm{NaOCl}$ alternating with $17 \%$ EDTA resulted in a more accentuated decrease in microhardness and significantly different from that observed with $\mathrm{NaOCl}$ alone $(p<0.01)$. The demineralizing effect of EDTA with consequent decrease of microhardness has been extensively demonstrated (5,12-14). The chelating action of EDTA solution induces an adverse softening potential on the calcified components of dentin and consequently a reduction in the microhardness was expected. Also, the dissolving action of $\mathrm{NaOCl}$ on the organic collagen components of dentin explains how the alternated irrigation with these solutions affects the hardness of dentin (6). The combination of $\mathrm{NaOCl}$ and EDTA at a 1:1 ratio increases the effect of the chelating agent. The combination of these solutions increases the $\mathrm{pH}$, producing an alkaline environment in which EDTA has higher affinity for calcium ions (17). Saleh and Ettman (7) reported similar results to those of the present study as they found that the 
use of $5 \% \mathrm{NaOCl}$ alternated with $17 \%$ EDTA reduced significantly root dentin microhardness. However, it has also been reported that the combination of $\mathrm{NaOCl}$ and EDTA can potentialize the erosion of the dentin walls when the smear layer is removed (18).

Reduced dentin microhardness could be beneficial under clinical conditions as it would allow rapid preparation and negotiation of tight root canals. However, the degree of softening and demineralization will affect the physicochemical properties of this heterogenic structure (6). Previous studies have shown that some procedures such as removal of dental tissue during instrumentation (19), canal space preparation to receive intraradicular retainers (20) and use of chemical substances (21) may increase the susceptibility to vertical root fracture. Kruzic and Ritchie (22) reported that the destruction of the collagen matrix in dental hard mineralized tissues results in a less tough, more brittle substrate that might precipitate fatigue crack propagation during cyclic stresses. The combined action of $\mathrm{NaOCl}$ and EDTA causing changes on collagen matrix and demineralization of root dentin with consequent exposure of collagen, respectively, results in a decrease of dentin microhardness, as observed in the present study. This effect probably contributes to increase the incidence of fractures and/or cracks. Rajassingham et al. (23) verified that alternate irrigation with $5 \% \mathrm{NaOCl}$ and $17 \%$ EDTA resulted in increases of tooth surface strain. Those authors explain that the alternate irrigation with $5 \% \mathrm{NaOCl}$ and $17 \%$ EDTA probably allows the alternate depletion of organic and inorganic material, with a greater accumulative depth of effect on dentine and therefore tooth surface strain. They also emphasize that the increase in strain, although significant, does not yet indicate whether it is sufficient to result in increased risk of tooth fracture due to fatigue.

It should be stressed that some factors, such as dentin permeability may favor or decrease the action of irrigating solutions. Pécora et al. (24) pointed out that when the pulp chamber floor consists of primary dentin and regular secondary dentin, the penetration of ions is more uniform than in the presence of reparative dentin. Due to the fact that the reparative dentin appears more amorphous, less tubular and less regular than primary dentin, the passage of fluids is hindered, since the reduction in the number of available dentinal tubules leaves this dentin without its principal path of penetration. Mjör (25) reports that the irregular secondary dentin forms more on the floor and the roof of the pulp chamber than on the lateral walls, while the regular (or physiological) secondary dentin forms during the entire life of a tooth as a response to physiological stimuli. In this way, it is quite possible that the dentin of the furcation area in adult patients is less affected by the mechanical alterations produced by the solutions.

From the results of the present study, it may be concluded that $17 \%$ EDTA, alone or in combination with $1 \% \mathrm{NaOCl}$ reduced significantly dentin microhardness at the furcation area in mandibular molars. Therefore, care should be taken during chemomechanical preparation of these teeth, especially those with weakened furcation area. More questions need to be answered as to the extent to which these chemical alterations may affect the compressive strength and fracture strength of dentin at the furcation area.

\section{RESUMO}

A proposta desse estudo foi avaliar o efeito do $\mathrm{NaOCl} 1 \%$ e do ácido etilenodiaminotetracético $17 \%$ (EDTA), de forma isolada e alternada, sobre a microdureza dentinária da região da furca de molares inferiores. A superfície oclusal e as raízes de vinte molares inferiores, recém extraídos, foram cortadas transversalmente e descartadas. Os espécimes foram distribuídos em 4 grupos ( $n=5)$ de acordo com a solução irrigante utilizada. As soluções empregadas foram EDTA 17\% (I), NaOCl 1\% (II), $\mathrm{NaOCl} 1 \%$ e EDTA $17 \%$ (III), e água destilada (IV) (controle). Os dentes foram incluídos em blocos de resina acrílica e cortados transversalmente. A hemi-secção que melhor representou a furca dental foi lixada e polida para a avaliação da microdureza Knoop. As medidas obtidas foram analisadas utilizando-se teste ANOVA seguido do teste de comparação múltipla de Tukey $(\alpha=0,05)$. Os resultados desse estudo mostraram que todas as soluções, exceto o grupo controle, diminuíram a microdureza dentinária. O EDTA não apresentou diferença estatística significante em relação ao $\mathrm{NaOCl} /$ EDTA $(p>0,05)$, mas foi diferente do $\mathrm{NaOCl}(\mathrm{p}<0,01)$. Os grupos do EDTA e NaOCl/EDTA mostraram a maior redução da microdureza. A solução de EDTA $17 \%$, associada ou não ao $\mathrm{NaOCl} 1 \%$ reduz, significantemente, a microdureza dentinária da furca de molares inferiores.

\section{ACKNOWLEDGEMENTS}

This study was supported by FAPESP (Grant\# 2010/12345-4).

\section{REFERENCES}

1. Kokkas AB, Boutsioukis AC, Vassiliadis LP, Stavrianos CK. The influence of the smear layer on dentinl tubule penetration depth by three different root canal sealers: an in vitro study. J Endod 2004;30:100-102.

2. Alfredo E, Silva SRC, Ozório JEV, Sousa-Neto MD, BrugneraJúnior A, Silva-Sousa YTC. Bond strength of AH Plus and Epiphany sealers on root dentine irradiated with $980 \mathrm{~nm}$ diode 
laser. Int Endod J 2008;41:733-740.

3. Scelza MF, Teixeira AM, Scelza P. Decalcifying effect of EDTA-T, $10 \%$ citric acid, and 17\% EDTA on root canal dentin. Oral Surg Oral Med Oral Pathol Oral Radiol Endod 2003;95:234-236.

4. Cathro P. The importance of irrigation in Endodontics. Contemp Endod 2004;1:3-7.

5. Sayin TC, Serper A, Cehreli ZC, Kalayci S. Calcium loss from root canal dentin following EDTA, EGTA, EDTAC, and tetracycline$\mathrm{HCl}$ treatment with or without subsequent $\mathrm{NaOCl}$ irrigation. J Endod 2007a;33:581-584.

6. Kinney JH, Marshall SJ, Marshall GW. The mechanical properties of human dentin: a critical review and re-evaluation of the dental literature. Crit Rev Oral Biol Med 2003;14:13-29.

7. Saleh AA, Ettman WM. Effect of endodontic irrigation solutions on microhardness of root canal dentine. J Dent 1999;27:43-46.

8. Slutzy-Goldberg I, Maree M, Liberman R, Heling I. Effect of sodium hypochlorite on dentin microhardness. J Endod 2004;30:880-882.

9. Silva PV, Guedes DF, Pécora JD, Cruz-Filho AM. Time-dependent effects of chitosan on dentin structures. Braz Dent J 2012;23:357361.

10. Dogan H, Qalt S. Effects of chelating agents and sodium hypochlorite on mineral content of root dentin. J Endod 2001;27:578-580.

11. Oliveira LD, Carvalho CAT, Nunes W, Valera MC, Camargo CHR, Jorge AOC. Effects of chlorhexidine and sodium hypochlorite on the microhardness of root canal dentin. Oral Surg Oral Med Oral Pathol Oral Radiol Endod 2007;104:125-128.

12. Cruz-Filho AM, Sousa-Neto MD, Savioli RN, Silva RG, Vansan LP, Pecora JD. Effect of chelating solutions on the microhardness of root canal lumen dentin. J Endod 2011;37:358-362.

13. De-Deus G, Paciornik S, Mauricio MHP. Evaluation of the EDTA, EDTAC and citric acid on the microhardness of root dentine. Int Endod J 2006;39:401-407.

14. Cruz-Filho AM, Silva RG, Pécora JD. Acción del EDTAC en la microhardness de la dentina radicular en diferentes tiempos de aplicación. Rev Odont Federal Latino Americana (FOLA) 1996;2:82-90.

15. Akcay I, Sen BH. The effect of surfactant addition to EDTA on microhardness of root dentin. J Endod 2012;38:704-707.

16. Eldeniz AU, Erdemir A, Belli S. Effect of EDTA and citric acid Solutions on the microhardness and the roughness of human root canal dentin. J Endod 2005;31:107-110.

17. Saquy PC, Maia-Campos G, Sousa-Neto MD, Guimarães LF, Pecora JD. Evaluation of chelating action of EDTA in association with Dakin`s solution. Braz Dent J 1994;5:65-70.

18. Niu W, Yoshioka T, Kobayashi C, Suda H. A scanning electron microscopy study of dentinal erosion by final irrigation with EDTA and $\mathrm{NaOCl}$ solution. Int Endod J 2002;35:934-939.

19. Zandbiglari T, Davids H, Schäfer E. Influence of instrument taper on the resistance to fracture of endodontically treated roots. Oral Surg Oral Med Oral Pathol Oral Radiol Endod 2006;101:126-131.

20. Sirimai S, Riis DN, Morgano SM. An in vitro study of the facture resistance and the incidence of vertical root fracture of pulpless teeth restored with six post and core systems. J Prosthet Dent 1999;81:262-269.

21. Sim TP, Knowles JC, Ng YL, Shelton J, Gulabivala K. Effect of sodium hypochlorite on mechanical properties of dentin and tooth surface strain. Int Endod J 2001;34:120-132.

22. Kruzic JJ, Ritchie RO. Fatigue of mineralized tissues: cortical bone and dentin. J Mech Behav Biomed Mater 2008;1:3-17.

23. Rajasingham R, Ng YL, Knowles JC, Gulabivala K. The effect of sodium hypochlorite and ethylenediaminetetraacetic acid irrigation, individually and in alternation, on tooth surface strain Int Endod J 2010;43:31-40.

24. Pecora JD, Costa WF, Maia-Campos G. A study of the dentinal permeability of the pulp chamber floor of human lower molars with separate roots. Braz Dent J 1990;1:17-24.

25. Mjör IA. Human coronal dentine: structure and reaction. Oral Surg $1972 ; 37: 810-823$ 